Website: ijetms.in Issue:6, Volume No.4, September-2020 DOI: 10.46647/ijetms.2020.v04i06.006

\title{
English Language: Unravelling the Secrets
}

\author{
Bindu John \\ SCMS School of Technology \& Management, Muttam, Aluva, Kerala \\ bindujohnescmsgroup.org
}

\begin{abstract}
English has surely walked an exceptionally long path, from humble beginnings in the streets of Angla-land to being the major language on earth. Once regarded as the language of the lower class, English is today a global power to be reckoned with, a force that pushes the world forward and a language with immense glory and a rich history. Propelled by the various works of eminent writers, English has been able to develop, grow and expand to a standardised language which holds the key to future. Through this article I would like to unravel the secrets of this language and to achieve the objective, we must travel through the various ages English and England has plodded.
\end{abstract}

Keywords - English, History, Standardised Language, Global Power

\section{INTRODUCTION}

English language is one of the predominant forms of communication, with its influences on +2 billion people globally. Computerization and globalization are the main reasons for the acceptance and spread of English language. At present English has become a lingua franca, a global language. It is a rich language with tens of thousands more words in its vocabulary than any other language. It is the most generally used language in international trade, mass entertainment, diplomacy, international telecommunications and scientific publications, publishing newspapers and other books.

In today's world, the knowledge of English language makes an individual literate, in contrast to the past where those who process degrees and diplomas were considered so. The command over the English language boosts up one's personality also. Now schools and universities give extra care in instilling communication skills in English due to the ocean of career opportunities and has become an inevitable requirement for several professions such as computing and medicine.

As a teacher, I have been witnessing the growth of English language day by day. Now the world has started to respect and accept those who speak this language well. It is a prestige language nowadays but only a few know about the journey of English language from its humble origins to the language that eased trade and communication in today's world. Most people consider English as a language used by the elite. Though it may be true to an extend today, its past speaks a different story.

Language is a great mystery and perhaps that is why we need to think about it more deeply and carefully. Evolution does not occur on its own. One's evolution may lead to another's demise. Accordingly, the evolution of English language has been influenced by many external factors. Through this article I would like to take you back to the origin of English language and the various ages through which it has transcended.

Why is there a need for studying the past of a language that can be used at ease today? The answer is the same as why we need to study the past of any culture, nation, institution, person, or idea. It gives us the base on which it was build, shows us how it has evolved into what we see or use today, and it also helps us in improving it further. What we create on a strong base stay strong.

\section{EXPLORATION OF ENGLISH LANGUAGE}

Language is something particular to humans and this essential ability to speak distinguishes humans from all other living things. As a communicative tool, language helps us to express our ideas and concepts, as well as moods, feelings, and attitudes. The enigmatic nature of language will begin to unfold itself once you realise that it cannot be studied in isolation. we know that language is a system of communication used by a country or community. Thus, English language is related to English people. This study focuses on the people and the periods through which English Language has commenced its journey. Quirks and inconsistencies aside, the history surrounding its monumental rise is both a fascinating and rich one. Let us start our exploration from the early settlers of England.

\section{EARLY SETTLERS IN ENGLAND}

We have only a limited information about the early settlers in England. As per the historical records Iberians were the first inhabitants in England, who came through the Iberian Peninsula from their home in Africa. We are unsure about their time period or contributions to England. After them Celts (600-55 BC) came and occupied the land. The new invaders, the Celts, pushed the Iberians away from 
Website: ijetms.in Issue:6, Volume No.4, September-2020 DOI: 10.46647/ijetms.2020.v04i06.006

their habitats towards the less hospitable north and the marshy west. Place names like Kent, London dover, river Thames, Wye were the contributions of Celtic language. After the celts, Romans (55BC-410 AD) conquered England in 55 B.C.

The first Roman expedition to Britain, under the command of Julius ceaser, 'The Glorious Star on Roman Firmament', took place in the year $55 \mathrm{BC}$. They ruled the country for more than four centuries. Their main contribution to English people was Christian faith. By the end of third century all the people in England accepted Christianity. The language in England before English was Latin which was the result of romanisation of the island.

\section{GERMANIC CONQUEST - DAWN OF ENGLISH LANGUAGE}

An event that profoundly affected the course of historywas the invasion of Britain by some Germanic tribes, after the depart of the Romans from the island of Britain about 449 AD. Venerable Bede's Ecclesiastical History of English People (731 AD) tells that the Germanic tribes who conquered England were the Jutes, the Saxons, and Angles. England comes from the word Angles. The newly conquered land was called 'Anglaland', or 'land of the Angles'. The writers called the language of these invaders as Englisc. And later the land and its people were called Anglecynn (Angle-kin). English is thus older than England. With the available information we can conclude that, English language took off with the invasion of Britain during the 5th century. English language as it is spoken today has risen from the dialects spoken by the Germanic tribes. Since then the evolution of English has been an unbroken one.

Contrary to our belief, the English language has never had an official standard. It has evolved through centuries and adopted many thousands of words through overseas exploration, international trade, and the building of an empire. It has progressed from a dialect of Germanic settlers in the 5th century, to a global language in the $21 \mathrm{st}$ century. To unravel the truths of English language, we have to travel through three English periods. The journey through these three periods is inevitable because these periods help us in reaching the present status of English in 21 st century.

\section{MAKING OF ENGLISH: Three PERIOdS}

More than 1500 year of its existence, English has developed incessantly. We can divide these developments in to three main periods. They are:

- Old English:450-1100

- Middle English:1100-1500

- Modern English: 1500 to the present

\section{OLD ENGLISH}

Old English was not exclusively a uniform language .we can identify four dialects in Old English, Northumbrian, Mercian,West Saxon and Kentish .West Saxon gradually gained ascendancy and the documents which enable us to study Old English are documents of West Saxon .

The period of Old English is a period of full inflections. In contrast to Modern English, Old English had three genders (masculine, feminine, neuter) in the noun and adjective. Nouns, pronouns, and adjectives were inflected for case. Noun and adjective paradigms had four cases (nominative, genitive, dative, and accusative) while pronouns also had forms for the instrumental case. Old English had strong verbs (called in contemporary grammars as irregular verbs) than does Modern English. The verbs which were strong in Old English are weak (regular) verbs in Modern English. The old English period was a multilingual period-A period with several languages being used simultaneously. English interacted with Celtic, Latin, and Scandinavian languages. English language borrowed words from other languages to enhance its vocabulary.

In vocabulary old English was very resourceful in the formation of words by means of prefixes and suffixes. It was possible to form more than a hundred words from the same root. This feature was widely used to form verbs with about twelve common prefixes. Another remarkable feature was the large number of self-explaining compounds. This capacity for forming new words by combining the existing ones and by deriving them with the help of prefixes and suffixes gave a remarkable variety and flexibility to Old English. This is apparent in its literature which is distinguished for its poetry.

The best recognized surviving example in Old English is the poem Beowulf. It is considered as the oldest known English poem and is notable for its length - 3,183 lines. It was written in Britain more than one thousand years ago and the author is anonymous. 
Website: ijetms.in Issue:6, Volume No.4, September-2020 DOI: 10.46647/ijetms.2020.v04i06.006

After Old English comes the Middle English Period, a lot of changes happened during this period which starts from $1100 \mathrm{AD}$ and lasts up to $1500 \mathrm{AD}$.

\section{The MiddLe English Period (1100 AD- 1500 AD)}

As mentioned before, it is in fact a period in which changes occurred in every aspect of the language. The greatest single factor for this was the conquest of England and the Anglo - Saxons by the Duke of Normandy, William the Conqueror, familiarly known as the Norman Conquest in $1066 \mathrm{AD}$. The new overlords spoke a language of Old French known as Anglo-Norman. The entire English nobility was replaced by French aristocracy and the French language robbed English of its rightful place. The influence of the Normans can be illustrated by these two words, beef, and cow. Beef, usually eaten by the aristocracy, taken from the Anglo-Norman, while the Anglo-Saxon commoners, who tended the cattle, kept the Germanic cow. Several legal languages, such as jury, indict, and verdict, have Anglo-Norman roots because the Normans were running the courts. Thus the words commonly used by the aristocracy have Romantic roots and words used normally by the Anglo-Saxon masses have Germanic roots. Thus, French language became the language of the elite groups and English became the language of the masses.

The situation got changed when King John lost the province of Normandy to the King of France in 1204 AD. This started a process where the Norman nobles of England became gradually more separated from their French cousins. England became the primary concern of the nobility, rather than estates in France, and as a result the nobility adopted modified English as their native tongue. The ruling class began to think in English and thus began the process of rehabilitation of English.

English language got supremacy over French language due to many reasons. The Hundred Years War made French the language of the enemy. It was a long conflict set against the kings and kingdoms of France and England from 1337 to 1453 over several issues. There were two factors for the origin of the conflict: first was, the kings of England wanted independent possession. Second, the kings of England, as the closest relatives of the last direct Capetian king (Charles IV, who had died in 1328), from 1337 claimed the crown of France. In the Wake of the Hundred Years' War, many English regarded French as the enemy's language. Consequently, the English people started to think about their own language and the status of the English language rose to a different level and as a result Oxford and Cambridge universities were founded. Thus literacy increased, Though the books were still hand-copied and expensive.

Another reason for the acceptance of English was Black death, a pandemic that devastated Europe between 1347 and 1351which had taken a proportionately greater toll of life than any other known epidemic or war up to that time. The most afflicted were the poor more than rich which made labour scarce. A more lasting and serious outcome was the drastic reduction of the amount of land under cultivation, due to the deaths of so many labourers. This proved to be the ruin of many landowners. The shortage of labour compelled them to substitute wages or money rents in place of labour services to keep their tenants. This resulted in the rise in wages for artisans and peasants. And this increased the social and economic importance of the labouring class and with it the importance of English language which they spoke than Anglo Norman. This combination of the two languages came to be known as Middle English.

The Resurgent middle English literature signifies the revitalised English language and its important place in English life. Fourteenth century is the age of Geoffrey Chaucer (1350-1400), the father of English poetry and the author of Troilus and Criseyde and The Canterbury Tales, William Langland the author of a long social allegory Piers Plowman and John Wycliffe (1384)translator of The Bible also belong to this age. The 15th century saw extended use of English as a literary medium and had several distinguished writers of prose such Malory, Lydgate, and Caxton. It was during the 14 th century that a different dialect (known as the East-Midlands) began to develop around the London area.

Geoffrey Chaucer, a writer we have come to identify as the Father of English Literature and author of the widely renowned Canterbury Tales, was often heralded as the greatest poet of that particular time. It was through his various works that the English language was "approved" alongside those of French and Latin, though he continued to write up some of his characters in the northern dialects.

Chaucer's The Canterbury Tales was the most wellknown masterpiece of Middle English ,an unfinished series of stories( written during the last 14 years of its author's life(1387 - 1400)) suggesting to be told by a group of pilgrims journeying from London to the shrine of St. Thomas Becket . Geoffrey Chaucer (1340-1400), who was the son of a wealthy wine merchant, weaves together stories told by 28 pilgrims whom the storyteller (the poet himself) met at an inn, epitomise all facets of English social life-aristocracy, clergy, commoners, and even a middle 
Website: ijetms.in Issue:6, Volume No.4, September-2020 DOI: 10.46647/ijetms.2020.v04i06.006

class, which was not officially familiar by the social structure of the day, but which, in fact, existed.

It may not seem unusual to modern readers that Chaucer wrote in the language that people in his area spoke, which is called vernacular. But it was a bold decision because most poets during that time were writing in an earlier version of the language such as French, or Latin, which were considered as the languages of scholars, religious figures, and upper-class people. As an upper-class, welleducated person himself, Chaucer would have been able to write in various languages. But he chose to write The Canterbury Tales in the vernacular of his country that more people would understand and connect to. For this reason, The Canterbury Tales is regarded as one of the first poems written in the English language, and Chaucer himself is one of the "fathers" of the written English language.

After 1349 English began to be used again in the schools. By 1362, the linguistic separation between the nobleness and the commoners was largely over. In that year, the act of pleading was accepted, which made English the language of the courts and it initiated to be used in Parliament. In the 15th century French became restricted as the language of culture and fashion. English now was once again adopted as the language for records of towns and guilds and in 1425 English came to be generally adopted in writing.

The English Renaissance sprouted during the end of the 15 th century. It was associated with the rebirth of societal and cultural movements. Though it was slow to gather steam during the initial phases, celebrated the heights of glory during the Elizabethan Age. The end of the 16th and start of the 17th century, English language was greatly influenced by the writings of actor and playwright, William Shakespeare. It is because he started writing during a time when the English language was undergoing serious changes due to contact with other nations through war, colonisation etc. These changes were further cemented by different writers. Shakespeare and other emerging playwrights realised that their ideas could not be expressed through the English language currently in circulation. So, they modified the adopted words or phrases from other languages and added to the English language, creating a richer experience for all concerned.

Accompanied by middle English comes the Elizabethan age, associated with the reign of Queen Elizabeth I (15581603) , considered the Golden Age of English literature,. The Elizabethan Age as part of the Renaissance period, rebirth of the arts, saw the development of Elizabethan poetry and the stability of England. Probably the most splendid age in the history of English literature was the
Elizabethan literature, contributed to the emergence of great writers namely Sir Philip Sidney, Edmund Spenser, Roger Ascham, Richard Hooker, Christopher Marlowe, and William Shakespeare. , Under Elizabeth's reign, drama became a unifying influence, drawing people of different social classes together and was not exclusively restricted to the gentry or upper class. Commoners and royalty could enjoy the same performance in each other's company, even though in separate seating arrangements.

The finest culmination in English language happened during this period, the Elizabethan age in general and due to the great Shakespeare in particular. With Shakespeare, English Literature was on the threshold of the modern period. Elizabeth's England truly became a Golden age because of Shakespeare, who came from the little village of Stratford on the banks of the River Avon. He was a boy who had only elementary grammar school education, a runaway to London to escape punishment for poaching in the Kings forest. In London, he did anything that a young man could do to earn his living .He thus got involved in the Elizabethan Theatre at all levels starting at the very bottom of the ladder and climbing up step by step to actor ,dramatist ,and finally shareholder in the Lord Chamberlain's players .He wrote on an average two plays during the years from 1588 to 1611 .He wrote comedies ,historical plays and tragedies .

The best manifestation of Shakespeare's genius is to be found in the great tragedies that he has crafted. His first tragedies were experimental ones. Titus Andronicus with its spectacular violence, Romeo and Juliet with its tragic adolescent love are different from the usual Elizabethan tragedies. Julius Caesar is not merely a political tale but the story of how men fall victim to a train of events which arise from wrong judgement, which they can do nothing to arrest .Each of Shakespeare's great tragedies is built on a truth which remains forever and changed by the progress of time . Thus, Hamlet is a revenged tragedy, Othello a domestic tragedy, King Lear a social tragedy, Macbeth the tragedy of overweening ambition and Antony and Cleopatra a heroic tragedy. The Tempest, the one in which he bids goodbye to his art of creating a magical world peopled by Kings and clowns, lovers and villains, fairies, and spirits, is the last of Shakespeare plays, The Elizabethan age came to an end with the death of Shakespeare.

\section{MODERN ENGLISH}

Modern period can be associated with the process of standardization. Grammatically, English settled down as an analytical language in the hands of Shakespeare and other writers. It had developed into a fit medium for both prose and poetry and conscious efforts were made to make it an 
Website: ijetms.in Issue:6, Volume No.4, September-2020 DOI: 10.46647/ijetms.2020.v04i06.006

appropriate vehicle for science. Many Spelling reforms were undertaken, dictionaries were composed, and English was transplanted to other lands through colonisation, giving rise to new, non-native varieties of English. Caxton's innovation of Printing Press was key in standardizing the English, something ,English learners should be grateful for

Many factors resulted in the standardization of English language. It started with the renaissance followed by the industrial revolution. The third was the migration and settlement in new lands like USA, Australia, Canada, and New Zealand. The fourth was the Imperial colonisation of Asian and African lands. All these have contributed to the making of modern English and towards making it a world language.

\section{A. Standardization Process in English Language}

The standardisation process proceeds in four interlinked stages. The process of standardization is an on-going one, and a whole range of forces are at work. The different stages are:

\section{a. Selection of the standard variety:}

Variability in regional dialects, class dialects, situational varieties are facts of life for almost all languages. Standardisation represents an attempt to minimise if not eliminate this high degree of variability. The easiest solution seems to select and elevate one of these varieties to the status of the standard.

\section{b. Acceptance of the functions of the standard:}

The 'acceptance' by the community of the norms of the variety selected over those of rival varieties, through the promotion, spread, establishment and enforcement of the norms. This is accomplished through institutions, agencies, authorities such as schools, ministries, the media, cultural establishments, etc.

\section{c. Elaboration of the functions of the standard:}

For the variety selected to represent the desired norms, it must be able to discharge a whole range of functions that it may be called upon to fulfil, including abstract, intellectual functions. Where it lacks resources to do so, these are developed. Thus, a standard language is often characterised as possessing 'maximal variation in function, minimal variation in form'.

\section{d. Codification:}

The norms and rules of grammar, use, etc. Which govern the variety selected must be formulated.it is an attempt to 'fix 'the standard variety in dictionaries and grammars, spellers, manuals of style, texts, etc.

Let us discuss these in detail.

\section{B. Selection of the East Midland dialect as the dominant variety}

The roots of the selection of standard variety of English lie with the merchant class based in London. Their spoken dialect was the East Midland dialect. By the end of the 14th century East Midland was an emergent written standard with variations in the dialect .After about 1430 ,one of these variants became progressively dominant because of its use in government and official documents along with being greatly reinforced and accelerated by the printing press .

It took some time for the East Midland speech of the London merchants to acquire prestige. Another reason for the acceptance of East Midland dialect was the role played by the universities in England. Students from around England came together in the two universities of Oxford and Cambridge ,only a few miles from London .London was the centre of trade. In the triangle formed by these three centres, a great deal of East Midlands speech would have been heard, and possibly used as a kind of Lingua Franca among a mobile social group .It would have helped to spread East Midland, because of its usefulness in communicating with the people who spoke another dialect .

There is also political dimension to the selection of the standard variety apart from the regional and social economic factors. when ideas about nationhood and political autonomy gained currency, a standard had emerged in England too like in France and Spain.

\section{Acceptance of the Standard:}

By the middle of the 15th century, East Midland dialect had been accepted as a written standard for official documents. But its acceptance was not specific: it was a matter of convention rather than a diktat. for example, Chaucer wrote in the East Midland dialect as it was spoken in London; but when his manuscript was reproduced, the dialect was silently altered by different scribes in different parts of the country- there was no sense of a literary norm. and by the 16th century, i.e. by the time of Shakespeare the standard variety was well established in the domain of literature .Acceptance of the standard, therefore ,occasions a rejection of kinds of English that are felt to be outside the norm . For instance, one dialect which was chosen by playwrights and others was Kentish. E.g.: Edgar's speech in King Lear. Such literary practises reflect the mounting awareness of a standard variety during the 16th century. By then actions were being made to define the standard, it had reached the stage of unambiguous acceptance. 
Website: ijetms.in Issue:6, Volume No.4, September-2020 DOI: 10.46647/ijetms.2020.v04i06.006

\section{Elaboration of Function}

At this Stage there was an effort to achieve the major goals of standardization: maximal usage in function. In the domains of law, government, literature religion scholarship and education, the new standard had to function wherein previously only Latin and French were used. It became mandatory to develop novel structures and new meanings appropriate to its use in different domains. Each group of Specialist- lawyers, writers of religious text, administrators -cultivated their own registers within the standard.

Let us examine certain elaboration of the functions of the Standard English Language.

There was a great deal of controversy among scholars on the use and potential of English as a literary medium. Scholars considered English unsuitable for composing great works of literature as according to them English was dull, cantered, and barbarous. By 1580s the controversy had subsided, and the balance had been achieved between native usage and foreign importation. English was declared to have achieved a state of eloquence by the works of great poets like Spencer ,Sidney and Shakespeare who had composed works that many felt were a competition for any literature .this instilled a new-found confidence among writers to conduct stylistic experiments .

Another important domain was that of religion. The 16th century saw a flurry of legal translation, preparation of prayer books and other Christian texts. This process of venularization culminated in the publication of the authorized version of the Bible in 1611.This version gave English what might be called classical variety of its own.

Inspired by the example of the Authorized version, writers began to nurture prose to such an extent that 17 th century became called the century of prose. A significant aspect of that trend was the increased use of language writing of a scientific and scholarly nature followed by developing interest in science and philosophy. People wrote political pamphlets, journals essays, and the first newspapers in English that enhanced use of English which in turn improved the status of the language.

Displacing Latin, English gradually became the language of education and Grammar schools were founded. and there was a gradual loosening of the church's hold on institutions of learning and literacy. The expansion of secular education increased the demand for learning of English.

\section{E. Codification}

It is the final stage of the process of standardization. Elimination of variation and stemming the process of change, constitute the stage called codification. In the codification of English, the example set by other languages is of immense importance. The codifiers looked back at classical Latin and envied the fixity and order of its grammar. Moreover, there were other models too to emulate. For a time, the idea of an English Academy was introduced and among its greatest advocates were figures like Swift, Dryden, and Defoe. But by the middle of the 18th century support for such an institution had diminished. As a result, certain substitutes to the Academy were recommended. These include books written or composed by established scholars and literary men.

The most famous was the Dictionary of Dr. Johnson. Dr.Johnson's dictionary is important not only in the field of spelling standardization but also in the sphere of the codification of words and meanings .His contribution lies in the fact that he provided an alphabetical list of all the words in the standard language with their meanings. $\mathrm{He}$ listed the range of meanings for each word including the widespread; and he illustrated each strand of meaning with the quotations from writers. In addition, he also provides certain facts about the nature of language, its history, and its grammar. The prestige enjoyed by the dictionary during the late 18th and early 19th century was enormous. The individuality of Johnson can be seen on almost every page of his dictionary. His work is a landmark in the history of standardization of English.

The second half of the 18th century was also the elevated water-mark for the codification of grammar.Although treatises on English grammar had begun to appear in the 16th century, and in the 17th century were compiled by authors such as Ben Johnson and Milton it was only in the 18th century that we find a striking outburst of interest in grammar . Certain traditional structures were replaced by more 'accurate' forms. For instance, the English pattern 'it's me' which had been common for centuries and still is, was deemed incorrect since it did not follow the Latin usage. Hence it was replaced with it is I. Another example is in relation to negation. According to traditional English pattern' I do not know nothing' signalled negation by the cumulative use of negative particles. By the end of the 18th century, this had been labelled illogical, by applying the rule that 'two negatives make a positive'. Thus, throughout the 18th century the grammarians were busy codifying rules about grammatical usage and the English we use today is largely a result of these reforms. 
Website: ijetms.in Issue:6, Volume No.4, September-2020 DOI: 10.46647/ijetms.2020.v04i06.006

Next important aspect to codify was Pronunciation. The English spelling is the most imperfect and inappropriate model for the sounds we make. People have felt bound by it for more than 400 years. In the 16 th century some scholars were attracted to the codification of pronunciation as it was a mixed variety of different areas and traditional spelling systems. Codification of the other levels of structure led to the production of the pronouncing dictionary. Thus, Johnson's dictionary had codified both words and spellings and now the spelling was virtually fixed. This process of codification of pronunciation was simultaneously accompanied by the elimination of certain sort of pronunciation. For instance, the most barbarous kind of pronunciation was that associated with the cockney speech of London and people were asked not to follow it .A pronunciation that may be described as codified grew up ,cultivated and were taught in public schools by the early 19th century. Thus, the process of standardization was intricately related to social, political, religious and educational factors.

The above-mentioned process helped to make English Language a standardised language and now it has been accepted as an international language.

\section{THE PRESENT STATUS OF ENGLISH LANGUAGE}

Now the importance of English in the modern world is quite large. Quite recently it was a foreign language for most of us, and today it is international. The study of English is of great importance in all countries of the world. Everyone dreams of studying it at least at the initial level. Today, children begin to learn this language even at preschool age. Many do not understand whether English is needed in the modern world. However, it is not a secret for anyone that today he plays an important role in the job placement. To find a prestigious and highly paid position people must necessarily know the English language well. Because of this reason, large firms often cooperate with foreign partners.

Modern English is an extremely diverse language which has absorbed much from many other languages. There are over 300 million native English speakers in the world, and between 400 and 800 million foreign speakers. It is the official language of air transport and shipping; the prominent language of science, technology, computers, and trade; and the major language used for education, publications, and international negotiations.

The world of today needs English for some of the following reasons:

\section{A. Internet:}

Internet plays a crucial role to promote and to spread the English language throughout the globe and more and more people are exposed to the English language and it has become the language of the internet as well.

\section{B. Education:}

The field of education has amplified the function of English Language. Most of the educational resources, materials and books are in English. The lack of English knowledge makes anyone insufficient in the realm of education in today's world.

\section{Communication:}

The most important function of a language is to communicate properly. To communicate successfully, one needs a language that is commonly understood by most of the people in the speech community. English becomes an efficient instrument to communicate with everyone around the world. Information technology uses this ability of English to function well in the field of communication by internet and emails.

\section{Travel:}

English is spoken around the globe next to Mandarin Chinese. It has been stated that out of the nearly six billion people living in the world today around three hundred and fifty million do speak English. It has become the International Business Language. Many countries around the world make use of English Language for the governance. The relationship among the countries around the world is enhanced by the effective communication in English. Language differs from nation to nation. When we travel around the globe, the English Language becomes the rescue factor to communicate with everyone.

\section{E. Business:}

English language has been the language of business in today's electronic world and it is the trading language of the world. A sound knowledge of English Language makes an individual to be a successful businessman around the world. A good number of companies have ventured into sending the production to overseas to cut down their costs. In other words, the companies around the world are in to outsourcing and offshoring business. To communicate with the businesspeople of other countries, English Language becomes the effective tool.

\section{CONCLUSION}

We would find no immediate resemblances between Modern English and Old English, when one endeavours to study various English language courses taught today. English grammar has become remarkably refined 
Website: ijetms.in Issue:6, Volume No.4, September-2020 DOI: 10.46647/ijetms.2020.v04i06.006

(smartphone messaging has made a mockery of the English language itself). The basic history and development of a language which was generated from the embers of wars fought between ferocious civilisations. Imagine the trials and tribulations that our descendants went through, their readiness to give up everything to achieve freedom of speech and expression. We are indebted to our great ancestors for standardising this language. But now we take it for granted when we have courses to improve English at the touch of a button. Maybe you are a fan of Shakespeare, John Milton, or J.K. Rowling etc. And all the great literary writers bring into life more than just words on a page but a living history that continues to evolve to this day.

The influence of English spread throughout the British Isles, during the medieval and early modern period. Its influence began to be felt throughout the world, from the early seventeenth century onwards. The reasons for the significant changes in English language were the complex processes of exploration, colonization and overseas trade that characterized Britain's external relations for several centuries. Words were taken from all over the world, often via the languages of other trading and imperial nations. At the same time, new varieties of English appeared, each with their own distinctions of vocabulary and grammar and their own distinct pronunciations. At present English has been accepted as a lingua franca, a global language, used and understood by many nations for whom English is not their first language

English is thus an incredibly old language. But the reason for its relevance even today is because it's ever evolving. The evolution of English is not restricted to a certain reason, but a variety of reasons be it social, economic, cultural, or political. The fact is that this international language is growing along with its speakers. Today English is not an endemic language because it has changed according to its surroundings. The very fact that there are many types of English like American, Indian, or Australian is evidence to this. Many words are being added to this language while many are forgotten. Thus, the evolution of English is an ongoing process. And this is the very reason English is relevant even today, after all only the fittest will survive.

\section{References}

[1] Aitchison, J.1996.The seeds of Speech: Language Origin and Evolution. Cambridge, Cambridge University Press.

[2] Churchill, Winston. A History of the English-Speaking People (Vol 1-12). London: Cassel and Co.,1966.

[3] Henry, Bradley. The Making of English.London.1904[A very, short readable study]
[4] Holmes, Janet. 1992.An Introduction to Sociolinguistics. London: Longman.

[5] Kress, G.R.1985 Linguistic Processes in Sociocultural Practice. Victoria: Deakin University Press.

[6] Otto Jespersen Growth and Structure of the English Language Oxford1905[Avery stimulating study that explains the grammatical changes in English]

[7] Trevelyan, G.M. Illustrated English Social History (vol 1-6) England: Penguin,1968 